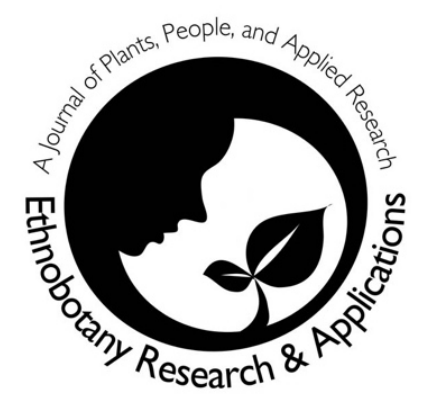

\title{
Hyphaene compressa, an important palm in the arid and semi-arid regions of Kenya
}

\author{
Agnes Omire, Johnstone Neondo, Nancy L.M. \\ Budambula, Robert Gituru, and Cecilia Mweu
}

\section{Research}

\begin{abstract}
Background: Peasant agroecosystems in Kenya are considered to be a continuum of integrated traditional farming systems and natural ecosystem conservancy programs. Hyphaene compressa (doum palm) exists in arid and semi-arid lands (ASAL) of Kenya. While research in these areas is focusing on new plants to be brought to the areas, there is no focus on doum palm, which is already adapted to these areas. Scanty ethnobotanical knowledge exists in the form of unpublished material. The study aimed to determine domestication status, management practices, important use categories, plant part value, biotic and abiotic stresses of $H$. compressa.
\end{abstract}

Methods: Four sampling sites in the ASAL of Kenya were selected. Tharaka Nithi, Kwale, Tana River and Turkana. Responses of 79 informants were analyzed to establish doum palm domestication profile, uses, biotic and abiotic stresses affecting its growth.

Results: The domestication status varied across the sampled areas, with most regions showing no willingness to domesticate the plant. The study revealed that doum palm has fourteen uses with food (fruit) use, and prevention of soil erosion (roots) recording the highest and the least fidelity level scores, respectively, in the sampled areas. The most observed biotic stress was human interference and pest infestation, while the observed abiotic stress was drought and salinity.

Conclusion:The most important doum palm use is food. Due to the high usage and poor domestication, doum palm could be losing its gene pool and hence genetic diversity studies are important for its conservation.
Key words: Doum palm, Hyphaene compressa, domestication, ethnobotany, ASAL, conservation, biotic stress, abiotic stress, uses, plant part value

\section{Correspondence}

Agnes Omire ${ }^{1}$, Johnstone Neondo ${ }^{2}$, Nancy L.M. Budambula $^{3}$, Robert Gituru ${ }^{1}$, and Cecilia Mweu ${ }^{2 *}$

1Department of Botany, Jomo Kenyatta University of Agriculture and Technology P.O BOX 6200000200 Nairobi, Kenya

${ }^{2}$ Institute of Biotechnology Research, Jomo

Kenyatta University of Agriculture and Technology P.O BOX 62000-00200 Nairobi Kenya

${ }^{3}$ Department of Biological Sciences, University of Embu P.O. Box 6-60100, EMBU, Kenya

*Corresponding Author: cmweu@jkuat.ac.ke

\section{Ethnobotany Research \& Applications} 20:4 (2020)

\section{Background}

Traditional agroecosystems constitute major in situ repositories of both crop and wild plant germplasm. Sustainable utilization of these plant resources directly depends on cultural farming practices (Dulloo et al. 2010). Hyphaene compressa H.Wendl., is a common palm growing in wadis and at oasis found in arid and semi-arid lands (ASAL) of Eastern African countries (Vandenbeldt 1992, Orwa et al. 2009). This palm grows well between $0-1400 \mathrm{~m}$ altitude, a mean annual temperature of above $28^{\circ} \mathrm{C}$ and a mean annual rainfall of $100-600 \mathrm{~mm}$ (Orwa et al. 2009). It is one of the few perennial plants vastly growing in ASAL. There are no known mechanisms for doum palm propagation and conservation in Kenya. 
Previous studies indicate that date (Phoenix dactylifera L.), coconut (Cocos nucifera L.), areca (Areca catechu L.) and African oil palm (Elaeis guineensis Jacq.) have been domesticated, but there is no documented evidence on doum palm domestication, despite its importance in predynastic Egypt (Clement 1992, Janick 2014). Doum palm was regarded as a sacred fruit in Egypt and fruits were discovered in ancient tombs of Pharaohs by archeologists (Hamdy \& Fahmy 2018).

The Arecaceae family is considered one of the three most economically important families, only surpassed by the Poaceae family (Balslev et al. 2016, Lee and Balick 2008). Palms support basic needs in rural populations, where they are used as construction materials, medicines, food and to generate income for the local families (Macía et al. 2011, Paniagua-Zambrana et al. 2007). However, the importance of palms goes beyond the local rural needs to international importance (Balslev et al. 2016). In West Africa, palms are much appreciated as non- timber products (Stauffer et al. 2017). Hyphaene compressa plays an important role in ASAL, where the populace use it as construction material, food, medicine and as an ornamental plant (Amwatta 2004). The nomadic pastoralists and agropastoralists in the ASAL of Kenya heavily depend on its leaves for economic empowerment and sustenance, through the sale of woven doum palm products (Amwatta 2004). The Turkana prepare a mixture of the fruit powder and cow blood which they call 'Lokot'. They prepare this food when getting ready for long journeys or migrating to new areas for greener pastures (Maundu \& Tengnass 2005). The fruits are also eaten by animals like donkeys, camels and goats. The young shoots and leaves are used as vegetables and fodder during drought (Maundu \& Tengnas 2005).

The cumulative information on uses of plants and their products is passed on from generation to generation (Gadgil et al. 1993). This knowledge, however, is threatened by the aging population and lack of interest among the youth in acquiring it, due to the influence of western culture and trends (Nolan \& Turner 2011). It is therefore important to protect traditional knowledge by thoroughly documenting it. In situ preservation of crops and wild plant genetic resources depends on proper documentation of their ethnobotany. Various methods are used to study the importance of plants in ethnobotany, including; descriptive studies, cultural consensus analysis, participatory methods and hypothesis testing (Stepp 2005). Various indices have been developed for quantifying and hypothesis testing of ethnobotanical data (Hoffman \& Gallaher 2007).
Despite the wide land coverage of $H$. compressa, there exists scanty formal documentation on its ethnobotany in Kenya. In addition, doum palm is already adapted to ASAL and can sustain the evergrowing population in these areas yet there is very little focus on it. This study aimed to determine the management practices and perceptions on domestication, biotic and abiotic stress, the important use categories and plant part value of $H$. compressa. This study employed Relative Cultural Importance $(\mathrm{RCl})$ indices that have been developed for quantifying ethnobotanical data (Hoffman \& Gallaher 2007). Data collected on these indices were analyzed and used to test the study's hypothesis that doum palm uses are random with respect to regions sampled.

\section{Materials and Methods Study area}

This study was done between January and September 2018 in Kenya. The four sampling sites (Fig. 1), namely Turkana (34 $30^{\prime}$ ' and $36^{\circ} 40^{\prime}$ 'East and $1^{\circ} 30^{\prime}$ and $5^{\circ} 30^{\prime}$ North), Tharaka Nithi (37 $19^{\circ}$ and $37^{\circ} 46^{\prime}$ East and $00^{\circ} 07^{\prime}$ and $00^{\circ} 26^{\prime}$ 'South), Kwale $\left(38^{\circ} 31\right.$ and $39^{\circ} 31^{\prime}$ 'East and $30^{\circ} 3^{\prime}$ and $40^{\circ} 45^{\prime}$ South) and Tana River $\left(38^{\circ} 25^{\prime}\right.$ and $40^{\circ} 15^{\prime}$ 'East and $0^{\circ} 0^{\prime}$ and $2^{\circ} 0$ ' South) were selected based on previous studies (Amwatta 2004, Maundu \& Tengnas 2005). These areas fall between agro-ecological zones $v$ to vii, which are characterized by residual rainfall, high temperatures and low vegetation cover (Jaetzold \& Schmidt 2009).

Turkana County, located in the northwestern part of Kenya, covering an area of $77,000 \mathrm{~km}^{2}$, is an ASAL with Lake Turkana and River Turkwell as the perennial sources of water. It has elevated temperatures between $20^{\circ} \mathrm{C}$ and $41^{\circ} \mathrm{C}$, irregular rainfall (mean annual rainfall of $200 \mathrm{~mm}$ ) and a population of 855,399 people (Turkana County government 2013). The ethnic groups in Turkana are the Turkana, Rendile, Elmolo, Pokot and Samburu (Turkana County Government 2013). The Turkana are a minority community in Kenya who are nomadic, a state which makes them vulnerable to persistent poverty (Ng'asike \& Swadener 2015). The county is considered a food stressed county with the main sources of food being wild fruits, livestock and relief food (Kenya interAgency rapid Assessment 2014). They keep zebu cattle, goats, donkeys and camels for milk, meat, wealth and dowry payment. Communities along Lake Turkana practice fishing (Turkana County government 2013). In this area, $H$. compressa is the predominant vegetation thus considered as forests of Turkana (Turkana County government 2013). Other plants growing include Acacia spp., Aloe spp., and Osyris lanceolata. 


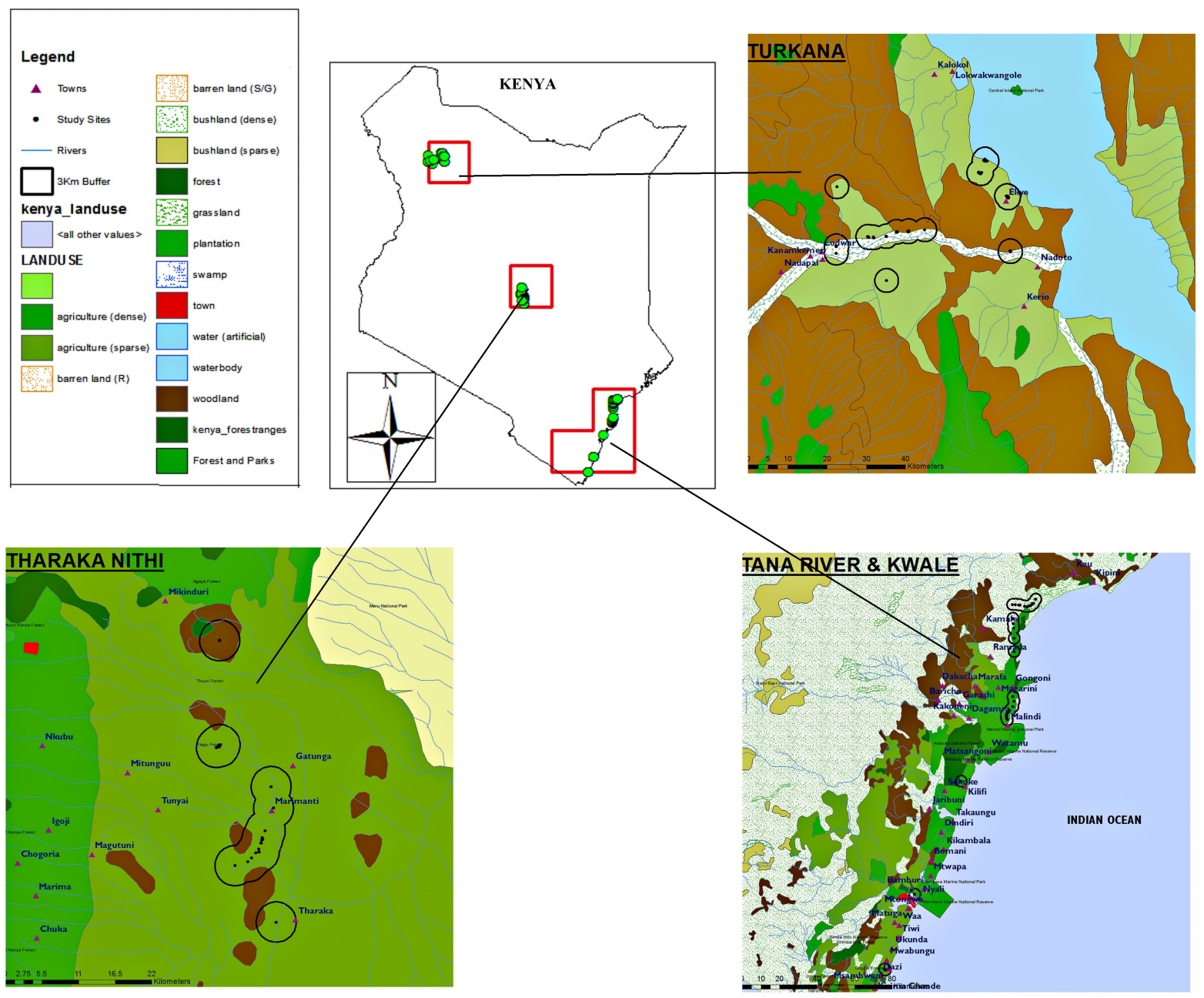

Figure 1. Map of Kenya showing sampling areas; Tharaka Nithi, Turkana, Tana River and Kwale counties in Kenya

Tharaka Nithi sub-county in Kenya is approximately $2610 \mathrm{~km}^{2}$, with a population of 365,330 people. It has an annual rainfall of 500 to $800 \mathrm{~mm}$ per year and temperatures between $29^{\circ} \mathrm{C}$ to $36^{\circ} \mathrm{C}$. The ethnic communities in Tharaka Nithi are, the Aatharaka and Nithi ethnic communities. The Tharaka Nithi people are agri-pastoralists specializing in food crops such as millet, sorghum, pigeon peas, green grams, and cowpeas and they keep dairy cattle, indigenous zebu cattle, goats, sheep and chicken (Icheria 2015). The main River Tana tributaries flowing through this area include Mutonga, Thingithu, Kathita, Thanantu, Thangatha, Kithinu and Ura rivers, which provide water for irrigation (County Government of Tharaka Nithi, 2017). The endowment with many rivers in the region is an impetus for fishing activities. The predominant vegetation cover consists of Acacia spp., with little drought-tolerant grass cover species (Gioto 2018). There are pockets of doum palm species on the mainland and along the rivers within the region.

Tana River County is classified as an ASAL, despite being home to the most important estuarine and deltaric ecosystem with a rich diversity of wildlife and plants in East Africa (https://www.tanariver.go.ke/ environmental-wildlife-and-natural-resources/). The county has a mean temperature of $23^{\circ} \mathrm{C}$ and max of $33^{\circ} \mathrm{C}$ and rainfall of between $400 \mathrm{~mm}$ and $750 \mathrm{~mm}$ (Kenya inter-Agency rapid Assessment 2014). The rare species of monkeys called mangabey are only found here, and their main food is doum palm (Maundu \& Tengnas 2005). It has a population of 240,735 under an area of $35375.8 \mathrm{~km}^{2}$. Tana River people are agri-pastoralists specializing in food crops such as coconut, cowpea, green grams, cassava, cashew nuts, maize, mangoes and they keep goats and cattle (MoALF 2016). The county is classified as an acute food insecurity zone and they practice weaving and meal skipping to cope with the food stress (Kenya inter-Agency rapid Assessment 2014). The dominant ethnic groups are the Pokomo who are farmers, Orma and Wardey who are pastoralists. Other tribes include Waata and Boni who are hunters and gatherers, Wailwana, malakote and Bajuni (http://www.tanariver.go.ke/about-us-2/). 
Kwale has a population of 649931 and an area of $8270 \mathrm{~km}^{2}$. The major economic activities include tourism, fishing and agriculture. The main communities here are the Mijikenda. They grow maize cassava, beans, cashew nuts, coconut, and mangoes and keep livestock such as the zebu cattle, goats and sheep (Kenya inter-Agency rapid Assessment 2014). The predominant vegetation cover consists of offshore mangrove forests along the Indian Ocean, wetland grass, coconut and doum palm.

\section{Data collection}

A total of 79 informants $38(48.1 \%)$ women and $41(51.9 \%)$ men belonging to the four sampling areas were interviewed in this study. Women were the highly assessed gender in Turkana and Tana River while male were the most interviewed in Kwale and Tharaka Nithi (Table 1). The low number of interviewees was partly due to scarcely populated areas and scarcity of key informants. The criteria for identifying the lead informants varied from one region to another. In Turkana field personnel of a Non-Governmental organization (NGO) known as Anglican Development Services guided the identification, location and led the interview administration. In Tharaka Nithi, Kenya Forestry Research Institute (KEFRI) personnel guided the survey, whereas in Tana River and Kwale, Kenya Nuts and Oil Crops Directorate personnel led the survey. The selection of informants was done using the snowball technique. Only customary users of $H$. compressa products were selected, interviewed and provided lead to the next interviewee. The lead question was on doum palm awareness (knowledge). The interviewed informants included farmers and businessmen.

Table 1. Number of informants across the four sampled counties in Kenya

\begin{tabular}{llllll}
\hline County & $\begin{array}{l}\text { Ethnic } \\
\text { group }\end{array}$ & Local Name & $\begin{array}{l}\text { Number of } \\
\text { interviewees }\end{array}$ & $\begin{array}{l}\text { Percentage of } \\
\text { Women (\%) }\end{array}$ & $\begin{array}{l}\text { Percentage of Men } \\
(\%)\end{array}$ \\
\hline Turkana & Rendile & eng'ol & 27 & 51.9 & 48.1 \\
Tana river & Pokomo & Mkoma & 27 & 55.6 & 44.4 \\
Kwale & Mijikenda & Mkoma & 10 & 30 & 70 \\
Tharaka & AaTharaka & muruguju & 15 & 40 & 60 \\
Nithi & Nithi & & & & \\
\hline
\end{tabular}

Personal observation, oral and semi-structured interviews were carried out to collect data on the four objectives of the study. The interview schedule used in this study had a mixture of closed and open-ended type of questions and was structured into four parts as shown in Table 2.

To gather unique and unanticipated information about doum palm ecology from the resident perspective, a couple of open-ended questions were included. In the same interview schedule, several closed-ended questions (dichotomous questions, Likert scale questions and fixed response questions) were included to generate more information on the study objectives. Additionally, observational questions (Interviewer's opinion) were also included to generate the researcher's perception of biotic and abiotic stress assessment and distribution, domestication and maintenance of the palm. All responses to filled interview schedules were coded in SPSS under category type of questions and ordinal questions. During the interview, interpreters were used in cases where the respondents were not able to effectively communicate with the interviewer or were illiterate.

Table 2. Structure of the interview schedule used for sample collection

\begin{tabular}{|c|c|}
\hline Part of Questionnaire & Aspects interviewed \\
\hline Demographic information & Name, gender, County, Ethnic group of the informant \\
\hline $\begin{array}{l}\text { Distribution, domestication and } \\
\text { maintenance }\end{array}$ & $\begin{array}{l}\text { Number, Distribution and seasonality, Management practices, Cropping } \\
\text { systems and Plants intercropped with } H \text {. compressa }\end{array}$ \\
\hline Uses of doum palm & $\begin{array}{l}\text { Plant parts uses (Leaves, stem, roots and fruits), special uses (Rituals, } \\
\text { medicinal, religious), marketing of } H \text {. compressa products }\end{array}$ \\
\hline Biotic/ abiotic stress & $\begin{array}{l}\text { Pests and diseases affecting doum palm production, abiotic stresses on } \\
H \text {. compressa }\end{array}$ \\
\hline
\end{tabular}

\section{Data analysis}

This study employed the following importance indices: Reported use (RU), Reported use Value Per Plant Part (RU Plant Part), Plant Part Value (PPV) in percentage and Fidelity Level (FL) in percentage (Hoffman and Gallaher 2007). Fidelity level is the measure of how often a use report was mentioned (Salako et al. 2018).

$$
\mathrm{FL}(\%)=x / n \times 100
$$


Where, $x$ is the total number of informants who have mentioned a specific use and $n$ is the total number of informants.

$\mathrm{RU}$ is the total number of uses reported for the plant.

RU Plant Part is the total number of uses for each plant part

Percentage PPV is the ratio between the total reported uses for each plant part and the total number of reported uses for the plant, that is

$\mathrm{PPV}=\Sigma \mathrm{RU}$ Plant part/ $\Sigma \mathrm{RU} \times 100$

For quantitative analysis of data, all weaving and derived products were grouped as handicrafts and construction and derived products as construction/building, to facilitate data analysis (Sadeghi \& Kuhestani, 2014). Univariate analysis was done for appropriate categories. A data analysis strategy linked to research objectives was adopted. This strategy involved initial summarizing and describing the responses to each of the questions. Data on category type and ordinal questions were analyzed and presented in the form of the frequency of responses using percentages. Cross tabulation was used to determine the association between two category types of questions. Chi square was used to identify differences in the use values in the different regions sampled. This was done to test the hypothesis that doum palm uses are random with respect to the regions sampled.

\section{Results}

\section{Distribution, domestication and maintenance of} doum palm

A total of $26(96.3 \%)$ out of 27 informants in Turkana reported having more than 15 doum palm trees in their farms. In Tana River, $51.9 \%$ of informants had between 1 and 5 plants in their farms. Turkana had the highest number in one farm compared to the rest of the sampling areas. The Residents of Kwale are well conversant with this plant. They were able to differentiate $H$. compressa into three varieties based on differences in morphological traits. They locally identified them as Mkoma, Mbiye and Mkoko. Only a few $(20 \%)$ informants in Tharaka Nithi were able to differentiate the varieties but did not assign them any names. The informants from Tana River and Turkana could not differentiate the species/varieties.

More than half the respondents interviewed in Tharaka Nithi (53.3\%), Tana River (55.6\%), and Kwale (80\%) supported domestication of $H$. compressa. Turkana had the least of respondents (11.1\%) supporting domestication. The frequency of intercropping doum palm and other crops was highest in Tharaka Nithi with $86.7 \%$ of informants intercropping at any stage of the palm's development and only $13.3 \%$ intercropping when it is mature (Fig. 2 A). Respondents from Kwale and Tana River do not intercrop $H$. compressa with other crops. However, in Turkana only $3.7 \%$ were willing to intercrop. All the Respondents from Tharaka Nithi practiced some form of maintenance, including pruning and weeding, whereas none in the other three counties undertook any maintenance.

Different crops such as pawpaws, bananas, mangoes, cowpeas, sorghum, millet, pigeon peas, green grams, oranges and cassava were intercropped with $H$. compressa in Tharaka Nithi (Fig. 2A, B). However, in Kwale, Tana River and Turkana counties, it occurs in the wild (Fig. 2 C, D). In Turkana, it is the main plant but other plants such as Prosopis juliflora and Acacia spp. are found to grow in the same locality. Coconut, cashew nuts, Acacia spp. and mangroves were observed to grow in the same ecological niche as $H$. compressa at the Kenyan coast (Kwale and Tana River).

\section{Uses of doum palm \\ $H$. compressa leaves as food}

Food uses of doum palm fruit were recorded in all the sampled regions as shown by the high-fidelity scores across all regions. Most $(90 \%)$ of the informants who recorded fruit use were from Kwale followed by Turkana, Tana River and Tharaka Nithi. The fruit is consumed by humans by crushing and eating the flesh or drinking the water inside to quench thirst during drought (Figure $3 \mathrm{~A}$ and $3 \mathrm{~B}$ ). The fruit can also be ground into powder and used as a food additive. The feed uses of this plant was recorded in all the regions sampled. The fruit is also eaten by animals in the ASAL (Table 3). They feed on the leaves and on fruits that are ripe and have fallen from the tree (Fig. 3C).

In Tharaka Nithi, the use of doum palm as food recorded the highest-fidelity score $(80 \%)$ while the use of fastening farm tools recorded the lowest score (6.7\%). In Tana River County, uses of doum palm as food recorded the highest score $(81.5 \%)$ while medicine and fodder recorded the least (7.4\%). In Kwale the most use was fruit as food $(90 \%)$, while feed (leaves) recorded the least $(10 \%)$. The most uses for Turkana was food (Fig. $3 \mathrm{~A}$ and $3 \mathrm{~B}$ ), while prevention of soil erosion was least, with the scores of 88.9 and $3.7 \%$ respectively. The use of leaves and fruits as animal feed was not as common as the use of the same for human food. This is supported by the lower fidelity for feed uses scores compared to food uses. 

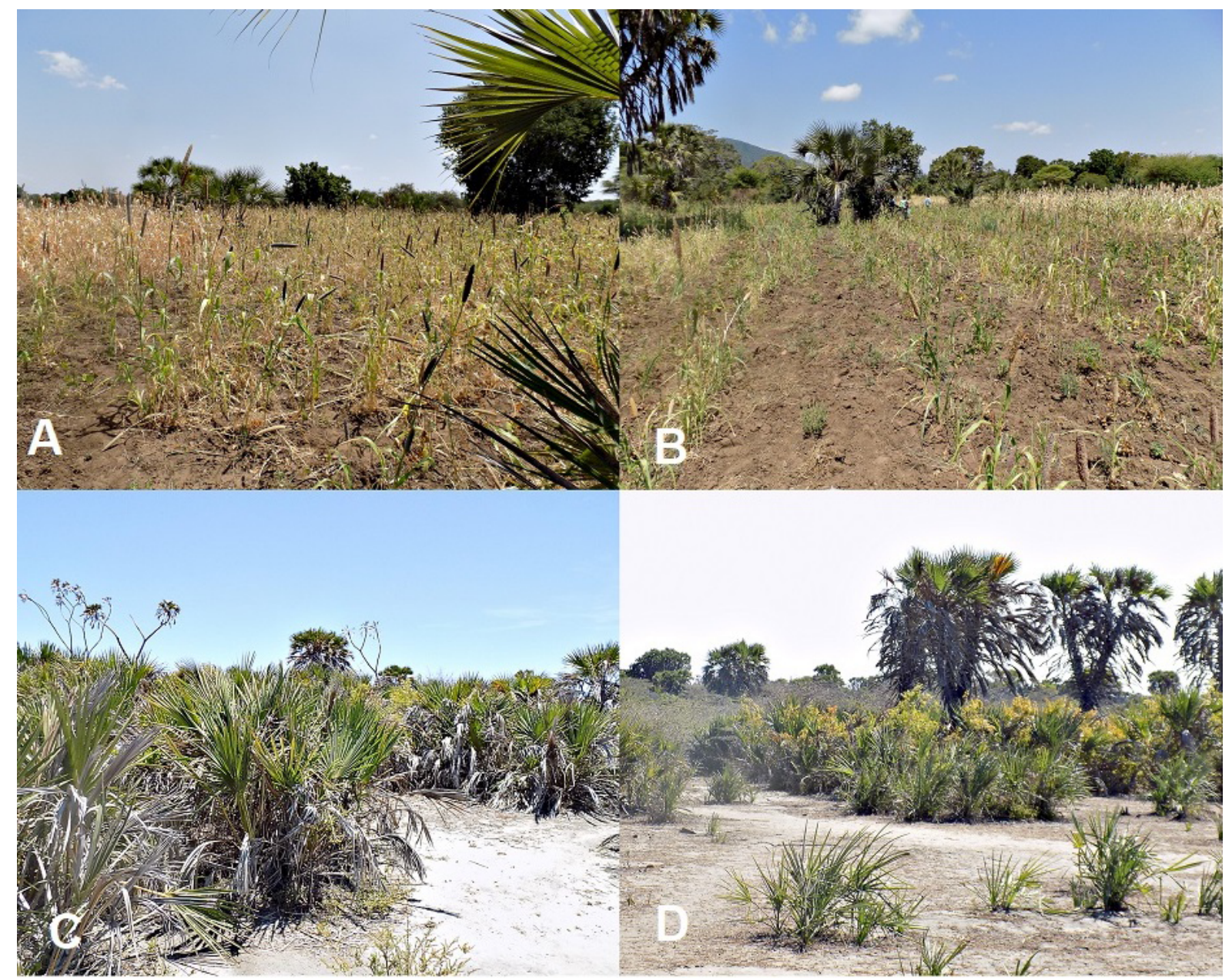

Figure 2. Doum palm intercropped with millet in Tharaka Nithi (A and B), doum palm growing in the wild in Tana River (C) and a bush of doum palm growing in Kwale (D)

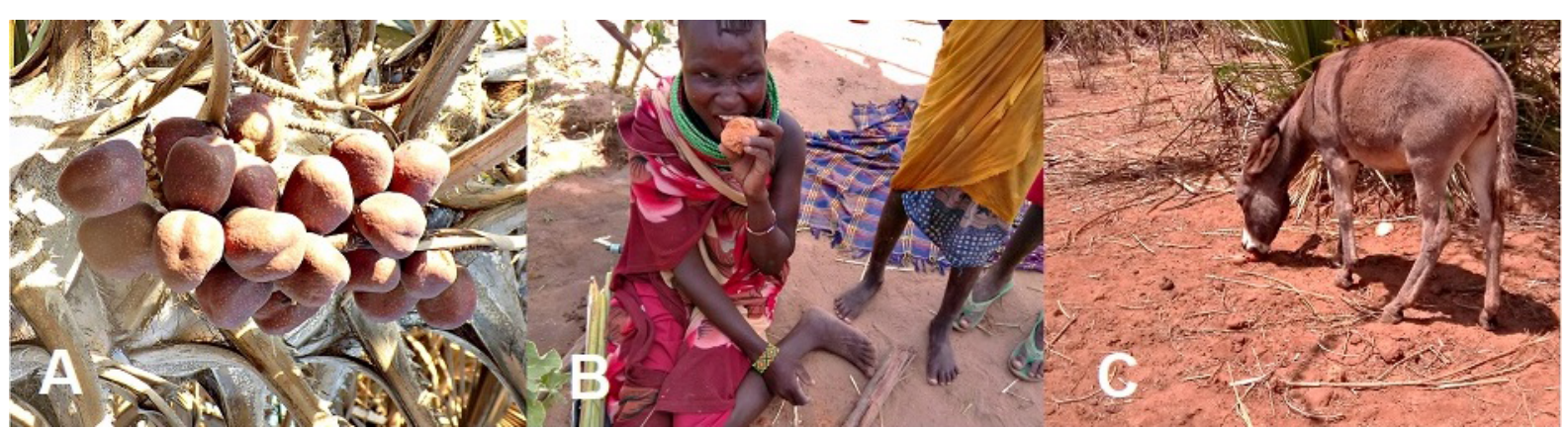

Figure 3. A. $H$. compressa fruits, B. A Turkana woman eating $H$. compressa fruit, C. A donkey eating $H$. compressa fruits that have fallen from the tree

\section{Medicinal uses of doum palm}

Three medicinal uses were noted in this study. In Kwale the fruit powder is used as a painkiller for headaches and the crushed inflorescence is used to treat miscarriage. Only $7.4 \%$ of informants from Tana River recorded the use of crushed leaves for treating burns (Table 3).

\section{H. compressa leaves for weaving}

The leaves for weaving are collected from juvenile palms preferably those with long mid ribs (Fig. 4A and $B$ ). Tharaka Nithi residents use leaves to make mats, baskets and brooms (Fig. $4 \mathrm{C}, \mathrm{F}, \mathrm{G}$ and $\mathrm{H}$ ). Weaving was noted to be done by women, men and children. However, women are frequent weavers (Fig. 4C). Local mat weavers in Turkana have modernized their baskets and mats by incorporating color and more articulate designs compared to Tharaka Nithi weavers (Fig.4 D and E). In Kwale County, doum palm leaves are used to make mats, baskets, ropes, fans and sieves (Fig. $4 \mathrm{I}, \mathrm{J}, \mathrm{K}$ and L). 
Table 3. Plant parts of doum palm used by different communities in Kenya and their fidelity levels

\begin{tabular}{|c|c|c|c|c|c|c|c|}
\hline \multirow{2}{*}{$\begin{array}{l}\text { Plant } \\
\text { Part }\end{array}$} & \multirow[t]{2}{*}{ Use Category } & \multirow[t]{2}{*}{ Uses } & \multicolumn{4}{|c|}{ Fidelity Level } & \multirow[t]{2}{*}{ P Value } \\
\hline & & & THK & TR & $\mathrm{KW}$ & TUR & \\
\hline \multirow[t]{5}{*}{ Fruit } & Food & $\begin{array}{l}\text { Fruit is crushed } \\
\text { Water inside is taken } \\
\text { Food additive }\end{array}$ & 80 & 81.5 & 90 & 88.9 & 0.568 \\
\hline & Feed & Donkeys, Camels & 26.7 & 18.5 & 10 & 48.1 & 0.046 \\
\hline & Fuel & Dry Husks are used & 40 & 55.6 & - & - & 0.001 \\
\hline & Medicine & $\begin{array}{l}\text { Powder as painkiller for } \\
\text { headaches } \\
\text { Inflorescence crushed and given } \\
\text { to expectant mothers to prevent } \\
\text { miscarriage }\end{array}$ & - & - & 20 & - & 0.267 \\
\hline & Other uses & $\begin{array}{l}\text { Fasten Farm tools-The husk is } \\
\text { put at the fulcrum for support. }\end{array}$ & 6.7 & - & - & - & 0.229 \\
\hline \multirow[t]{4}{*}{ Leaves } & Handicrafts & $\begin{array}{l}\text { Weaving mats, brooms, ropes, } \\
\text { fishing nets, sieves, hats }\end{array}$ & 53.3 & 70.4 & 60 & 74.1 & 0.589 \\
\hline & Medicine & Leaf ashes for treating burns & - & 7.4 & - & & 0.267 \\
\hline & Roofing & Thatching houses & 33.3 & 74.1 & 70 & & 0.033 \\
\hline & Feed & Donkeys, Camels, goats & 26.7 & 7.4 & 10 & 22.2 & 0.396 \\
\hline \multirow[t]{4}{*}{ Stem } & Construction & Furniture, houses, boats & 73.3 & 20 & 80 & 66.7 & 0.834 \\
\hline & Wine making & $\begin{array}{l}\text { Apical meristem is cut to tap } \\
\text { wine }\end{array}$ & - & 37.03 & 40 & - & 0.000 \\
\hline & Ornamental & As hedge & 20 & - & - & - & 0.004 \\
\hline & Other uses & Building Pet Houses & 26.7 & - & 20 & - & 0.013 \\
\hline Roots & $\begin{array}{l}\text { Prevention of } \\
\text { Soil erosion }\end{array}$ & Prevent soil erosion & - & - & - & 3.7 & 0.583 \\
\hline
\end{tabular}

\section{H. compressa for construction material}

Doum palm log is cut and used for construction (Fig. 5A). In Tharaka Nithi, doum palm trunk and leaf petioles are used as material for house/granary construction and pet house construction (Fig. $5 \mathrm{C}$, E). The petioles are used for making furniture (Fig. 5 D). In Tana River, doum palm is the predominant material for house construction (Fig. 5B). The local communities use palm leaves for thatching mud houses. In Turkana, the residents use doum palm trunks to construct boats for fishing. They make boats by cutting 3 to 5 medium size trunks and tying them together using ropes woven from doum palm leaves.

\section{Other uses of $\boldsymbol{H}$. compressa}

The fruit is also used for fastening farm tools. This is done by inserting the husk to the fulcrum of the hoe (Fig.5 F).). Wine tapping was indicated in Tana River and Kwale (Fig. $5 \mathrm{G}$ and $\mathrm{H}$ ). The residents tap the sap from the apical meristem to make wine. The tapping of wine was observed to be destructive. In some instances all the branches are cut leaving the plant with no leaves.

\section{Biotic and abiotic stress in $\mathbf{H}$. compressa}

The most observed biotic stress was human interference and pest infestation, while the observed abiotic stress was drought and salinity (Table 5, Figure 6). Doum palm in Tharaka Nithi recorded the highest biotic stress, including pest infestation (Fig. 6D) and human interference. In Tharaka Nithi harvesting is destructive to juvenile palms making them stunted (Figure $6 \mathrm{~A}$ and $\mathrm{B}$ ). The observed biotic stress in Turkana, Kwale and Tana River consisted mainly of Human interference $(30 \%, 25 \%$ and $20 \%$ respectively). Turkana and Tana River county recorded severe drought effects on doum palm plants while Tharaka Nithi and Kwale the drought effects were moderate (Table 5). Turkana, Tana River and Kwale displayed symptoms of salinity effects on doum palm (Table 5, Fig. 6C). 


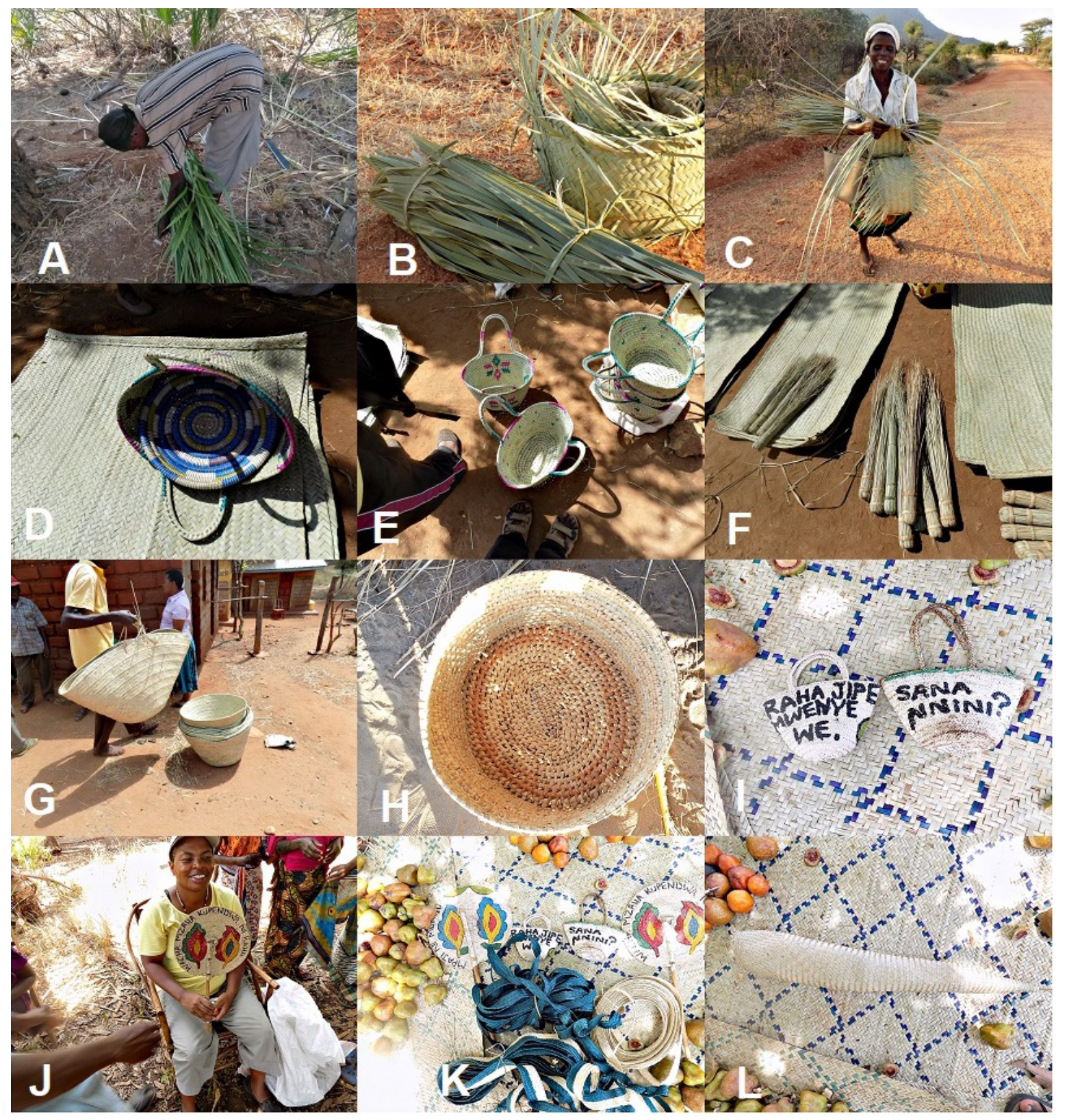

Figure 4. Handcraft from $H$. compressa; Woman from Tharaka collecting $H$. compressa leaves for weaving (A), Leaves ready for weaving in Tharaka Nithi (B), woman weaving baskets in Tharaka Nithi (C), Modernized baskets made from $H$. compressa by women in Turkana ( $D$ and $E$ ), mats, baskets and brooms made by people from Tharaka Nithi ( F, G and H), baskets, fans, ropes and mats by women from Kwale (I, J, K and L).

Table 4. Reported Use value per plant part and Plant part value of $H$. compressa among four counties in Kenya

\begin{tabular}{|c|c|c|c|c|c|c|c|c|c|c|}
\hline \multirow{2}{*}{$\begin{array}{l}\text { Plant } \\
\text { Part }\end{array}$} & \multirow{2}{*}{$\begin{array}{l}\text { Overall } \\
R U_{\text {Ppt }}\end{array}$} & \multirow[b]{2}{*}{ PPV } & \multicolumn{2}{|c|}{ Tharaka Nithi } & \multicolumn{2}{|c|}{ Tana River } & \multicolumn{2}{|l|}{ Kwale } & \multicolumn{2}{|c|}{ Turkana } \\
\hline & & & $\mathbf{R U}_{\mathrm{Ppt}}$ & PPV & $R U_{\text {Ppt }}$ & PPV & $\mathbf{R U}_{\mathrm{Ppt}}$ & PPV & $\mathbf{R U}_{\mathrm{Ppt}}$ & PPV \\
\hline Fruit & 5 & 35.7 & 4 & 40 & 3 & 33.3 & 3 & 33.3 & 2 & 28.6 \\
\hline Leaves & 4 & 28.6 & 3 & 30 & 4 & 44.4 & 3 & 33.3 & 3 & 42.8 \\
\hline Stem & 4 & 28.6 & 3 & 30 & 2 & 22.2 & 3 & 33.3 & 1 & 14.3 \\
\hline Roots & 1 & 7.1 & - & - & - & - & - & - & 1 & 14.3 \\
\hline RU & 14 & & 10 & & 9 & & 9 & & 7 & \\
\hline
\end{tabular}

$\mathrm{RU}_{\mathrm{Ppt}}$ is Reported use per plant part, RU: Reported use, PPV: Plant Part Value in percentage 


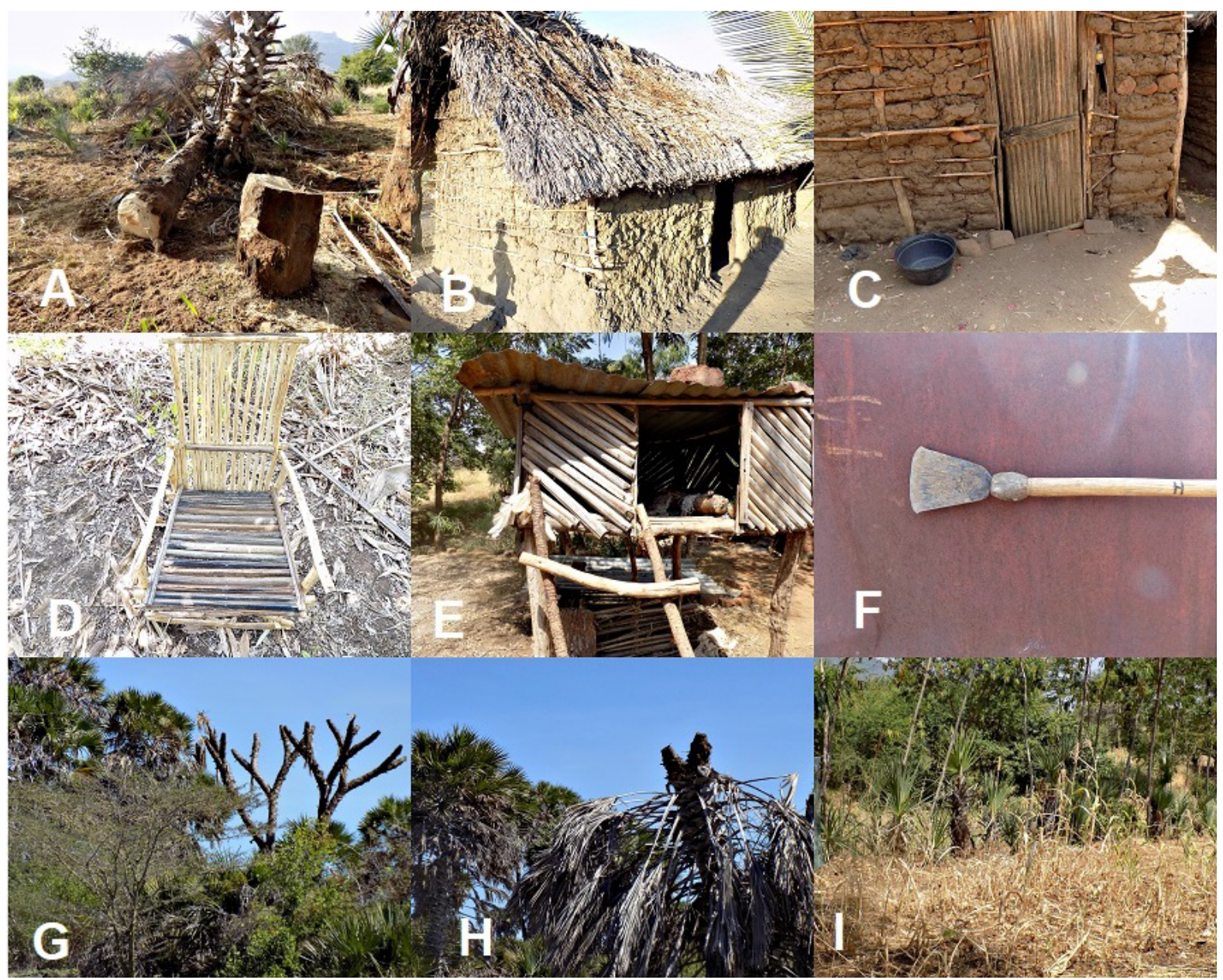

Figure 5. Construction and other $H$. compressa uses; log of $H$. compressa ready for use in Tharaka Nithi (A), Mud hut roofed with $H$. compressa leaves in Tana River (B), door made of $H$. compressa in Tharaka Nithi (C), Chair in Kwale (D), pet house in Tharaka Nithi (E), hoe arm fastened using $H$. compressa fruit in Tharaka Nithi (F), Stem cut for tapping wine by the coastal communities in Tana River and Kwale respectively $(G$ and $H)$ and doum palm used as a hedge (I).

Table 5. Biotic and abiotic stress as recorded in the sampled areas

\begin{tabular}{|c|c|c|c|c|}
\hline Sample Area & $\begin{array}{l}\text { Biotic stress } \\
\text { Morphological descriptor }\end{array}$ & Percentage (\%) & $\begin{array}{l}\text { Abiotic stress } \\
\text { Descriptor }\end{array}$ & Range \\
\hline Tharaka Nithi & $\begin{array}{l}\text { Leaf rust/pest infestation } \\
\text { Human interference } \\
\text { (Overharvesting, logging, burning } \\
\text { and clearing for human } \\
\text { settlement) }\end{array}$ & $\begin{array}{l}73 \\
60\end{array}$ & Drought & Moderate \\
\hline Turkana & $\begin{array}{l}\text { Leaf rust/pest infestation } \\
\text { Human interference (logging and } \\
\text { burning) }\end{array}$ & $\begin{array}{l}11 \\
30\end{array}$ & $\begin{array}{l}\text { salinity } \\
\text { Drought }\end{array}$ & Severe \\
\hline Kwale & $\begin{array}{l}\text { Human interference (leaf } \\
\text { overharvesting, wine tapping, } \\
\text { logging and burning) }\end{array}$ & 25 & $\begin{array}{l}\text { Salinity } \\
\text { Drought }\end{array}$ & Moderate \\
\hline Tana River & $\begin{array}{l}\text { Human interference (leaf } \\
\text { overharvesting, wine tapping, } \\
\text { logging and burning) }\end{array}$ & 20 & $\begin{array}{l}\text { Salinity } \\
\text { Drought }\end{array}$ & Severe \\
\hline
\end{tabular}




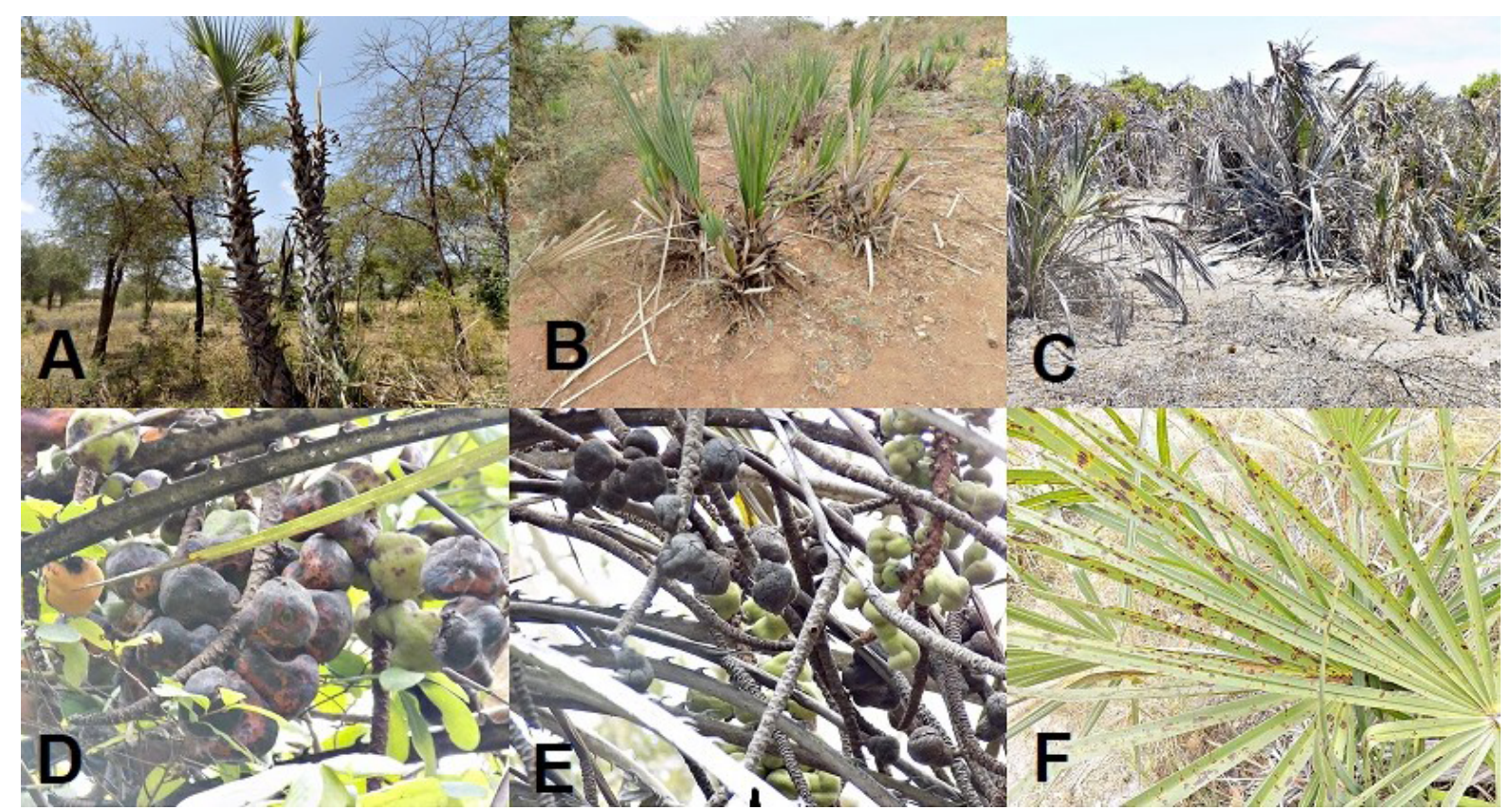

Figure 6. Biotic and abiotic stress of $H$. compressa; Overharvesting of leaves in Tharaka Nithi (A and B), effects of high salinity in Tana River (C), fruit infection in Tharaka and Kwale (D) and leaf rust in Turkana (D)

\section{Discussion}

This study highlights the importance of $H$. compressa to the local communities living in ASAL of Kenya. It is one of the few perennial plants that grows in these areas. Farmers in Tharaka Nithi do not clear it from the field during land preparation. They prune, weed and intercrop it. According to Vodouhè et al. (2011), the first step to domestication of wild plants includes maintenance in the field due to established uses and sustenance. In the second step, farmers are now interested in the plant and they weed and protect it. A domesticated plant is one that is fully dependent on man for its survival (Clement, 1992) and by this definition, $H$. compressa is therefore a semi domesticated plant. The motivation for its maintenance in Tharaka Nithi has been noted to be leaf production, high population density in Tharaka Nithi and the industrious nature of its residents (Amwatta 2004, Icheria 2015). Most weavers purchase bundles of leaves from farmers who have it on their farms. The farmers in turn continue to maintain it as a source of income. The need for maintenance in Tharaka Nithi is an indication that it could be losing its diversity which has adverse implications on conservation. On the other hand, Turkana had the highest $H$. compressa density of all the regions sampled and some little intercropping albeit with no maintenance activities. The lack of maintenance and propagation among the Turkana is partly due to the high population of $\mathrm{H}$. compressa. The trees which grow along the rivers are the most predominant vegetation and thus considered to be the forests of Turkana (Turkana County government, 2013). The Turkana also depend on humanitarian aid and food relief from various government and
NGO which has possibly influenced their attitude towards the maintenance of $\mathrm{H}$. compressa ( $\mathrm{Ng}$ 'asike \& Swadener 2015).

The presence of many NGOs in Turkana that support agricultural activities is a likely cause for the existence of observed intercropping activities aimed at supplementing the wild fruits, livestock products and relief food ( $\mathrm{Ng}$ 'asike \& Swadener 2015). Due to the heightened tourism activities in Kwale, the demand for doum palm products is high and hence the reason for high willingness to domesticate the plant (Kenya inter-Agency rapid Assessment 2014). Tana River residents expressed a high willingness to domesticate the plant due to the destructive process of tapping wine. Earlier studies reported that doum palm was an important plant in ancient Egypt, yet there is poor evidence of domestication (Clement 1992, Venugopal et al. 2017, Janick 2014).

This study documented 14 uses of doum palm. Fruits were the most used plant parts followed by leaves, stems and roots. In contrast, in an earlier study done on $H$. compressa, the leaves were the most used plant part (Amwatta, 2004). The present study observed that its most important use was human food for the people living in Tharaka Nithi, Turkana, Kwale and Tana River as indicated by the use index. The findings are in agreement with previous studies on palms which reported food being one of the important uses of Borassus aethiopum, coconut and date palm (Salako et al. 2018, Sadeghi and Kuhestani 2014, Stauffer et al . 2014). In all the sampled regions, the fruit mesocarp is used as food and feed. However, other peculiar uses of the fruit 
were also documented. For example, in Turkana, residents drink fruit sap as a beverage and also mix crushed mesocarp with livestock blood and use it as a meal (popularly known as 'lokot'). Residents of Tharaka Nithi use dry fruits as fuel and dry endocarp to fasten farming tools while residents of Kwale use crushed mesocarp as a food additive and as a herbal painkiller. Worth noting was the use of immature inflorescence by Kwale community as herbal medicine for expectant mothers to prevent miscarriage. Previously, Maundu et al. (1999) reported the use of doum palm fruit as food (lokot) among the residents of Turkana. The Turkana are a minority community in Kenya who are nomadic, a state which makes them vulnerable to persistent poverty ( $\mathrm{Ng}$ 'asike \& Swadener 2015). The area also experiences long seasons of drought necessitating alternative nourishment. During this time, they only have their livestock and plenty of doum palm fruits. In a study by Lokuruka (2008) doum palm fruit was shown to have high content of unsaturated fatty acids and are considered healthier than those from coconut or palm kernel oils. Earlier ethnobotanical studies on the palm family reported diverse medicinal utilities including but not limited to antiinflammatory, anti-diabetic, anti-biotic and antineoplastic agents (Gruca, et al. 2014, Nagata et al. 2011, Venugopal et al., 2017). Hyphaene thebaica fruits have been shown to be sources of effective antioxidants (Hsu et al. 2006). In Egypt, doum palm is used in the treatment of various ailments including hypertension (El-Rashad \& Hassan 2005). Doum palm can thus be explored further for medicinal properties.

The doum palm fruit is a major food source for animals like donkeys, camels and goats in all the four sampled areas. This is similar to previous findings which also noted that $H$. compressa fruits are food sources to other animals like elephants, baboons, monkeys and Mangabey (Maundu \& Tengnas 2005). Apart from $H$. compressa fruits being a source of feed, $H$. compressa leaves are always evergreen in these environments offering sufficient fodder for the livestock.

The common leaf uses in all the regions include weaving mats and trays, making brooms, thatching houses and animal feed. In Tana River, leaf ash is used to treat burns while in Kwale it is used to make fans, hats, sieves, ropes, and fishing nets. In Turkana, the leaves are used to make baby coats, food warmers and fishing nets. Due to their nomadic nature Turkana, residents use leaf petioles to make temporary huts called manyattas. On the other hand, in Tharaka Nithi, Kwale and Tana River leaves are used for thatching mud houses. Amwatta (2004) reported similar doum palm leaf uses. Whereas the present study determined human food to be the most important use of doum palm, a recent review reported leaves as the most important doum palm part used in making various woven products like mats, brooms, ropes and baskets (El-Beltagi 2018). Tana River and Kwale reported the least use of leaves as feed. This could be due to the fact that they belong to the humid agroecological zones due to the Indian Ocean where there is some variety of vegetation for animal feed while Tharaka Nithi and Turkana are in the dry semi arid and arid zones.

Doum palm stem is used for the construction of houses, granaries and fences. The stem is also tapped for wine in Kwale and Tana river. Only Turkana residents acknowledged the importance of doum palm roots in soil erosion prevention. In some regions, wood prepared from male doum palm trees is considered better than that from the female (ElBeltagi 2018). There were differences in doum palm uses as feed, fuel and roofing across all the sampled regions.

The existing doum palm plants in the studied regions exhibited symptoms of biotic and abiotic stress. For instance, there was overharvesting of doum palm leaves and insect infestation in Tharaka Nithi. Tana River and Kwale regions are saline and prone to drought. Doum palm is one of the few perennial plant species found in saline soils and can withstand erratic hostile climate conditions (Orwa et al. 2009, Venugopal et al. 2017). Previous studies have indicated that Kenyan coastal saline soils are rich in sodium carbonates and chlorides while Turkana saline soils are rich in sodium chloride (Mugai, 2004). High salinity is a soil feature prevalent in the arid and semi-arid areas. The tapping of wine from this plant, among other uses, was the predominant biotic stress recorded in Kwale and Tana River. This is because wine tapping is destructive to the apical meristems of the plant.

\section{Conclusions}

This study shows that part of doum palm growing in the ASAL of Kenya is semi- domesticated. Its maintenance practices include pruning and weeding particularly in Tharaka Nithi. The most important use of doum palm is food from the fruit. Human interference, salinity and drought are the most stresses of this plant. There was difference in doum palm uses as feed, fuel and roofing across all the sampled regions. This plant has economic uses in Kenya despite its limited species/varietal information. The rising exploitation of doum palm in Kenya calls for concerted in situ and ex situ conservation efforts. 


\section{Declarations}

List of Abbreviations: KW Kwale; PPV Plant Part Value; RU Reported Use; RU Plant Part Reported use per plant part; THK Tharaka Nithi County; TR Tana River County; TUR Turkana County

Ethics approval and consent to participate: Research permit and approval was granted by the Kenya National Commission for Science, Technology and innovation (NACOSTI). A prior informed consent was presented to the respondents stating clearly the objectives of the research and the potential impacts or output of the research. Those who consented to the research were the only ones allowed to participate. They were also informed that they had the right to refuse to be interviewed at any stage of the interview.

Consent for publication: Signed informed consent for publication was obtained from individuals in Figure 3 and 4.

Availability of data and material: All data generated or analyzed during this study are included in this published article

Competing interests: The authors declare that there are no conflicts of interest

Funding: This research was funded by National Research Fund (NRF) Kenya through a research grant Number NRFI1MMCl285.

Authors' contributions: $\mathrm{CM}, \mathrm{JN}$ and NLMB conceived the work, CM, JN and AO collected the data, $A O$ analyzed the data, $A O$ prepared the manuscript with assistance from CM, JN, NLMB and RG. All authors read and approved the final manuscript.

\section{Acknowledgements}

We would like to acknowledge the People of Turkana, Tharaka Nithi, Kwale and Tana River for sharing their traditional knowledge. The Kenya National Research Fund for funding this project. We also appreciate Nuts and Oil Crops Directorate (Agriculture and Food Authority) in Mombasa, Kenya Wildlife Service (Tharaka Nithi), The Anglican Development Services, Lodwar and the National Museums of Kenya for their logistic support and scientific guidance.

\section{Literature cited}

Amwatta CJM. 2004. Diversity of use of doum (Hyphaene compressa) in Kenya. Palms 48(4):184190.

Balslev H, Bernal R, Fay MF. 2016. Palms - emblems of tropical forests. Botanical Journal of the Linnean Society 182:195-200.

Clement CR. 1992. Domesticated palms. Principes, 36(2), 70-78.
County Government of Tharaka Nithi. 2017. Republic of Kenya County Government of TharakaNithi, First county integrated development Plan, 2017. Nairobi Kenya.

Dulloo ME, Hunter D, Borelli T. 2010. Ex situ and in situ conservation of agricultural biodiversity : major advances and research needs. Not.Bot.Hort.Agrobot.Cluj 38(2):123-135.

El-Beltagi H, Mohamed H, Yousef H, Fawz E. 2018. Biological activities of the doum palm ( Hyphaene thebaica $L$.) and its its bioactive components. In Antioxidants in food and its applications. Edited by $E$ Shalaby \& GM Azzam, Intechopen, pp. 49-65. doi: 10.5772/intechopen.74772

El-Rashad A, Hassan ZM. 2005. Potential utilization and healthy effects of doum fruits in ice cream and sesame butter (tehena). Alex.Journal of Food Science and Technology 2(1):29-39.

Gadgil M, Berkes F, Folke C. 1993. Indigenous knowledge for biodiversity conservation. Ambio, 22(3):151-156.

Gruca M, van Andel TR, Balslev H. 2014. Ritual uses of palms in traditional medicine in sub-Saharan Africa: A review. Journal of Ethnobiology and Ethnomedicine 10(60):1-24. doi: 10.1186/17464269-10-60

Hamdy R, Fahmy AG. 2018. Study of plant remains from the embalming cache KV63 at Luxor, Egypt: Progress in African archaeobotany. In Plants and people in the African past. Edited by A Mercuri, CD'Andrea, F Rita, \& H Alexa, Springer International Publishing. Switzerland, Pp. 40-56 doi: 10.1007/9783-319-89839-1

Hoffman B, Gallaher T. 2007. Importance indices in ethnobotany. Ethnobotany Research and Applications 5:201-218. doi: 10.17348/era.5.0.201218

Hsu B, Coupar IM, Ng K. 2006. Antioxidant activity of hot water extract from the fruit of the doum palm, Hyphaene thebaica. Food Chemistry 98:317-328. doi: 10.1016/j.foodchem.2005.05.077

Icheria BK. 2015. A social narrative on Tharaka people in Kenya, Africa. International Journal of Humanities Social Sciences and Education 2(2):4955.

Jaetzold R, Schmidt H. 2009. Farm management handbook of Kenya. In Natural Condition and Farm Management Information. Ministry of Agriculture and German Agricultural Team (GTZ):Nairobi.

Janick J. 2014. Agriculture: Origins of Agriculture in Egypt. Springer Reference 1-18. 
Kenya interAgency Rapid Assessment 2014. Kwale Secondary Data Review 2014. Nairobi Kenya.

Lee R, Balick MJ. 2008. Palms, people and health. Explore 4(1):59-62.

Lokuruka MNI. 2008. Fatty acids in the nut of the Turkana doum palm (Hyphaene coriaceae). African Journal of Food Agriculture Nutrition and Development 8(2):118-132.

Macía MJ, Armesilla PJ, Cámara-leret R, Paniaguazambrana N, Villalba S, Balslev H. 2011. Palm uses in Northwestern South America: A quantitative review. Botanical Review 77:462-570. doi: 10.1007/s12229-011-9086-8

Maundu P, Tengnas B. 2005. Useful trees and shrubs for Kenya. Technical handbook number 35. Nairobi, Kenya: World Agroforestry Centre- Eastern and Central Africa Regional Programme.

MoALF. 2016. Climate Risk Profile Tana River County.Kenya county Climate Risk Profile Series. The Ministry of Agriculture, Livestock and Fisheries (MoALF). Nairobi, Kenya.

Mugai EN. 2004. Salinity characterization of the Kenyan saline soils. Soil Science and Plant Nutrition 50(2):181-188.

doi:

10.1080/00380768.2004.10408467

Nagata JM, Jew AR, Kimeu JM, Salmen CR, Bukusi EA, Cohen CR. 2011. Medical pluralism on Mfangano Island:Use of medicinal plants among persons living with HIVIAIDS in Suba District, Kenya. Journal of Ethnopharmacology 135(2):501-509. doi: 10.1016/j.jep.2011.03.051.Medical

Ng'asike TJ, Swadener BB. 2015. Turkana indegenous knowledge, environmental sustainablity and pastoralist lifestyle. In Advances in Innovation Education. Edited by SE Huaman \& B Sriraman, Sense Publishers, Netherlands Pp. 107-12

Nolan JM, Turner NJ. 2011. Ethnobotany: The study of people-plant relationships. pp. 133-147. doi: 10.1002/9781118015872.ch9

Orwa C, Mutua A, Kindt R, Jamnadass R, Anthony S. 2009. Hyphaene thebaica ( $\mathrm{L}$.) Mart. In Agroforestree database:a tree reference and selection guide Pp. 1-5.

Paniagua-Zambrana NY, Byg A, Svenning JC, Moraes M, Grandez C, Balslev H. 2007. Diversity of palm uses in the western Amazon. Biodiversity and Conservation 16(10):2771-2787. doi: 10.1007/s10531-007-9218-y
Sadeghi Z, Kuhestani K. 2014. Ethnobotany of date palm (Phoenix dactylifera) in Baluch Tribe of Saravan region, Baluchistan, Iran. International Journal of Agricultural Technology 10(6):1563-1571. doi: 10.1016/j.neuron.2012.11.028

Salako KV, Moreira F, Gbedomon, RC, Tovissodé F, Assogbadjo AE, Glèlè Kakai RL. 2018. Traditional knowledge and cultural importance of Borassus aethiopum Mart. in Benin: Interacting effects of socio-demographic attributes and multi-scale abundance. Journal of Ethnobiology and Ethnomedicine 14(1):1-16. doi: 10.1186/s13002018-0233-8

Stauffer FW, Ouattara D. Stork A. 2014. Palmae (arecaceae) / Tropical African Flowering Plants, $8(1): 326-354$.

Stauffer FW, Ouattara DN, Roguet D, da Giau S, Michon L, Bakayoko A, Ekpe P. 2017. An update to the African palms (Arecaceae) floristic and taxonomic knowledge, with emphasis on the West African region. Journal of Plant Taxonomy and Geography 72(1):17-30. doi: 10.1080/00837792.2017.1313381

Stepp JR. 2005. Advances in ethnobiological field methods. Field Methods 17(3):211-218. doi: 10.1177/1525822X05277459

Turkana County government. 2013. Turkana county integrated development plan 2013-2017 (2013). Retrieved from http://www.nafis.go.ke

Vandenbeldt R. 1992. Problems with range-wide provenance trials of Faidherbia albida on sandy soils in Niger. In Vandenbeldt RJ (Ed.):Proceedings of a Workshop, ICRISAT-ICRAF (pp. 83-86). Nairobi, Kenya.

Venugopal A, Rinu KA, Joseph D. 2017. Cocos nucifera: It's pharmacological activities. World Journal of Pharmaceutical Sciences 5(8):195-200.

Vodouhè R, Dansi A, Avohou HT, Kpèki B, Azihou F. 2011. Plant domestication and its contributions to in situ conservation of genetic resources in Benin. International Journal of Biodiversity and Conservation 3(2):40-56. 


\section{Questionnaire for Recording Ethnobotany Data}

GPS Coordinates of sampling sites

\section{DEMOGRAPHIC INFORMATION}

a) Description of the farmer

a. Name of the farmer.

b. Gender.

b) County

c) Date

d) Ethnic group.

\section{DISTRIBUTION AND DOMESTICATION OF DOUM PALM}

a) Do you know doum palm? Respondent to show the interviewee a doum palm tree in his farm - Yes

- No

b) Seasonality

- Available only in season

- Available throughout the year

c) How many trees of Doum palm are in in your farm

\begin{tabular}{ll}
$\circ$ & $1-5$ \\
$\circ$ & $5-10$ \\
$\circ$ & $10-15$ \\
\hline & More than 15
\end{tabular}

d) Have you observed any varietal differences in doum palm?

- Yes

- No

e) If yes, how many varieties of doum palm can you identify?

f) Name them

g) What is the distribution of doum palm

○ widely distributed

- Limited

- Endangered

h) Is it worthy to domesticate doum palm?

○ Yes

- No

i) Cropping System

1. Monoculture

2. Intercropping

j) Does it allow intercropping?

○ Yes

○ No

○ Only when mature 
k) Plants intercropped with doum palm.

I) Do you do any form of maintenance of doum palm on the farm?
- Yes
- No

m) How do you maintain doum palm in your farm?.

\section{USES OF THE PLANT}

a) How do you use the doum palm fruit?

b) How do you use doum palm leaves.

c) How do you use doum palm stem.

d) How do you use doum palm roots.

e) Are there special uses of doum palm

1. Feasts

2. Religious purpose

3. Medicine

If yes, describe the use.

f) Economic uses

1. Export

2. Local consumers

3. Traditional industries

4. Handicrafts

\section{BIOTIC AND ABIOTIC STRESS}

(a) Is doum palm affected by pests

If yes describe the pest.

(b) Is doum palm affected by diseases

If yes describe the disease.

(c) Human interference (Harvesting by farmers, logging, clearing)
1. High
2. Moderate
3. No/ low

(d) browsing by animals
1. High
2. moderate
3. Low

e) Signs of Salinity stress

f) Signs of Drought Stress. 